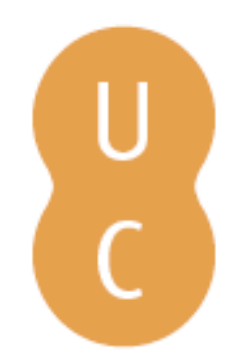

\title{
Rompalina
}

\section{Understanding unburned patches patterns in extreme wildfire events: a new approach}

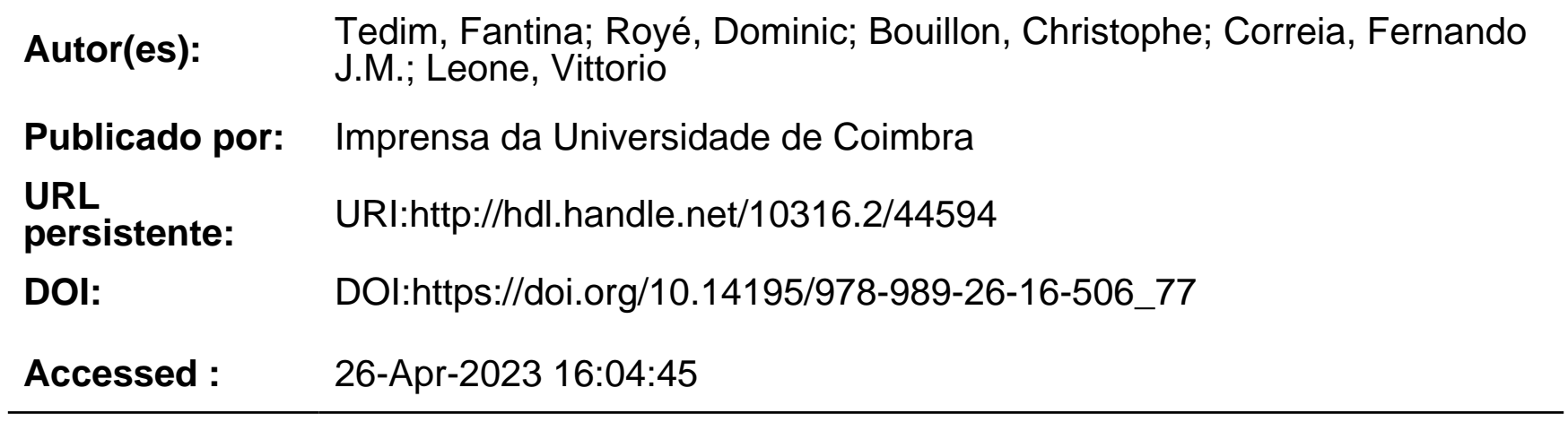

A navegação consulta e descarregamento dos títulos inseridos nas Bibliotecas Digitais UC Digitalis, UC Pombalina e UC Impactum, pressupõem a aceitação plena e sem reservas dos Termos e Condições de Uso destas Bibliotecas Digitais, disponíveis em https://digitalis.uc.pt/pt-pt/termos.

Conforme exposto nos referidos Termos e Condições de Uso, o descarregamento de títulos de acesso restrito requer uma licença válida de autorização devendo o utilizador aceder ao(s) documento(s) a partir de um endereço de IP da instituição detentora da supramencionada licença.

Ao utilizador é apenas permitido o descarregamento para uso pessoal, pelo que o emprego do(s) título(s) descarregado(s) para outro fim, designadamente comercial, carece de autorização do respetivo autor ou editor da obra.

Na medida em que todas as obras da UC Digitalis se encontram protegidas pelo Código do Direito de Autor e Direitos Conexos e demais legislação aplicável, toda a cópia, parcial ou total, deste documento, nos casos em que é legalmente admitida, deverá conter ou fazer-se acompanhar por este aviso.

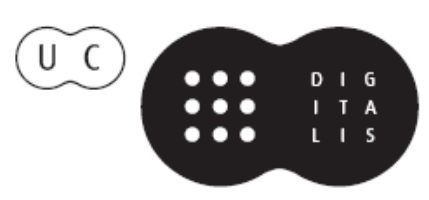




\section{ADVANCES IN}

\section{FOREST FIRE RESEARCH}

\section{8}

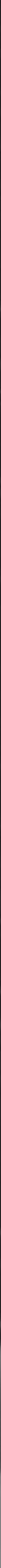




\title{
Understanding unburned patches patterns in extreme wildfire events: a new approach
}

\author{
Fantina Tedim $^{1,2}$; Dominic Royé ${ }^{1,3}$; Christophe Bouillon ${ }^{4}$; Fernando J.M. Correia ${ }^{1}$; Vittorio \\ Leone ${ }^{5}$ \\ ${ }^{1}$ University of Porto, Faculty of Arts, Via Panorâmica s/ $n^{\circ} 4150-564$ Porto, Portugal, \\ \{ftedim@letras.up.pt*\} \\ ${ }^{2}$ Charles Darwin University, Darwin, Australia \\ ${ }^{3}$ University of Santiago de Compostela, Faculty of Geography and History, Praza da \\ Universidade, $n^{o}$ 1, 15782 Santiago de Compostela, Spain, \{dominic.roye@usc.es\} \\ ${ }^{4}$ Irstea, RECOVER research unit, Mediterraneans Ecosystems and risks team, Aix-en-Provence, \\ France, \{christophe.bouillon@irstea.fr\} \\ ${ }^{5}$ University of Basilicata (retired), Department of Crop Systems, Forestry and Environmental \\ Sciences, Via dell'Ateneo Lucano 10, I-85100 Potenza, Italy, \{vittorioleone40@gmail.com\}
}

\begin{abstract}
Burned area is a rather weak descriptor of wildfire activity, since it is not well correlated neither with fire severity and ecological effects, nor with socio-economic impacts. It ignores the heterogeneity in severity distribution within fire boundaries, and the existence of unburned patches (UPs). The purpose of this paper is to provide a first understanding of the trends and spatial patterns and characteristics of UPs within wildfires in Portugal as well as their explanatory variables. This research adopts a special focus on extreme wildfire events (EWEs), that represent a huge threat to society because of their high intensity, erratic behavior, and strong spot activity. Previous studies on UPs mainly followed an ecological approach, whereas our research is mainly focused on understanding how the area of wildland-urban interface (WUI) contributes to create UPs inside an EWE. This focus is of paramount importance to assist prevention and mitigation, in order to increase the safety of people and assets, in a context of more extreme fire environments. We selected as case study the Pedrógão Grande wildfire that occurred in 2017. This event is one of the most disastrous fires ever occurred worldwide, with the highest number of fatalities in a single event. We hypothesize that even in this category of fires it is possible to find UPs. Based on the wildfire perimeter dataset available, we estimated the UPs by the application of geometrical operations. The mapping of WUI was carried out by methods developed by IRSTEA and available in the Ruimap software. The WUI map was created by a combination of housing configuration and vegetation characterization or land use map. To relate the formation of UPs and the Pedrógão Grande fire intensity we used the shape file of the isochrons of fire spread provided by the Independent Technical Commission (CTI) created by the Portuguese Parliament to investigate 2017 wildfires. We created an UPs georeferenced database for Pedrógão Grande wildfire comprising several variables (e.g. size, land use characteristics, aspect, slope). Although the trend of UPs in Portugal from 1975 to 2017 is presented, the most innovative findings are related with the study case of Pedrógão Grande and the patterns and characteristics of UPs within this fire perimeter. This wildfire burned with different intensities and rate of spread but since the first thirty minutes after the ignition, fire burned above the extinction capacity (CTI 2017). In this EWE, unburned area within fire boundary were identified irrespective of fire intensity values, even in the most critical period when fire burned with intensity up to $60,000 \mathrm{kWm}^{-1}$. Our findings corroborate the previous studies but others are in contrast with what has been published so far. One of the most interesting findings is that the largest UPs were formed in the interval of maximum intensity and are of the Mix UPs type. The implications of the findings of this research in land and wildfire management are exploited.
\end{abstract}

Keywords: Extreme wildfire events (EWE), fire intensity, Portugal, unburned patches (UPs), wildland-urban interface (WUI).

Advances in Forest Fire Research 2018 - Page 700 


\section{Introduction}

The number of fire events and burned area (BA) are the most widely used metrics to characterize wildfires and evaluate their impacts. BA is a rather weak descriptor of wildfire activity, since it is not well correlated neither with fire severity and ecological effects (Keane et al. 2009; Lutz et al. 2011; Kolden et al. 2012; Birch et al. 2014; Tedim et al. 2015) nor with socio-economic impacts (Gill and Moore 1998; Tedim et al. 2018). In addition, it ignores the heterogeneity in severity distribution, and the existence of unburned patches (UPs) within a fire perimeter, also labeled unburned islands, fire islands, refugia, or inclusions; they are an important component of the burned mosaic (Kolden et al. 2012; Kolden et al. 2015; Krawchuk et al. 2016)

UPs can be considered a response of landscape matrix to a wildfire event, and can help to retrace its dynamics, because they represent a physical evidence of local changes of fire behavior with heterogeneous consumption of fuels (Meddens et al. 2018), as influenced by several biophysical and anthropic drivers and their complex interactions. UPs contribute to create landscape heterogeneity and can thereby influence the distribution and behavior of subsequent wildfires. UPs "are landscape legacies that can provide an essential environment for species sensitive to fire, and support populations that contribute to the reassembly of biotic communities after fire" (Krawchuk et al. 2016: p. 2). However, UPs size, shape, frequency, and spatial patterns are usually not considered in current fire regime descriptions (Kolden and Weisberg 2007; Kolden et al. 2012; Meddens et al. 2018).

Research on UPs has mainly followed an ecological approach, focusing on their role: as fire refugia for fire-sensitive organisms; as seed sources facilitating the regeneration of adjacent burned areas, biodiversity conservation, increase in a post fire landscape, reduction of detrimental fire impacts on hydrology and erosion (Meddens et al. 2018); and in ecological trajectories of succession, ecosystem dynamics, and wildfire risk (Kolden et al. 2012).

The pattern of UPs distribution inside fire boundaries can be very variable (Kolden et al. 2012; Tedim et al. 2013; Leonard et al. 2014). Research has shown that the number of UPs significantly decreases with increasing fire size and severity (Kolden et al. 2012). UPs size increases with the extent of fire boundary, but patches decrease in density, whereas an increase in fire intensity produces smaller size Ups (Kolden et al. 2012; Kolden et al. 2015; Meddens et al. 2018). The ecological effects of UPs are determined by size (Eberhart and Woodard 1987), and edge effect (Slik et al. 2011). Enhancing the knowledge of UPs characteristics and the factors that contribute to their formation is crucial to produce accurate modeling, predict the efficacy of localized fire prevention and mitigation actions (Corona et al. 2014; Vaillant et al. 2016; Meddens et al. 2018).

The purpose of this paper is to provide a first understanding of the spatial patterns and characteristics of UPs in extreme wildfire events (EWEs), as well as their explanatory variables in Portugal. EWEs are pyro-convective phenomena overwhelming the capacity of control (fireline intensity $\geq 10,000 \mathrm{kWm}^{-1}$ ), exhibiting erratic and unpredictable fire behavior and spread; they can likely cause relevant negative socio-economic and environmental impacts (Tedim et al. 2018). This category of wildfires represents a huge threat to society but we hypothesize that even in occasion of these events it is possible to find UPs. Although recognizing the importance of the ecological role of UPs, our research is also focused on understanding how the area of wildland-urban interface (WUI) contributes to create UPs in case of EWE, which is of paramount importance to assist prevention and mitigation, in order to increase the safety of people and assets in a context of more extreme fire environments.

In the first part of this paper, the trend of UPs distribution and size for the period from 1975 to 2017 in Portugal is analyzed. In the second part, a detailed analysis is provided for the UPs occurred in the 2017 wildfire season. In the third part, the spatial pattern and characteristics of UPs in the Pedrógão Grande wildfire are presented, which is one of the several EWEs that occurred in 2017, in Portugal. 


\section{Data and methods}

\subsection{Study area and fire history}

The 2017 wildfire season was the worst one experienced by Portugal so far, since about 465,567ha were affected, i.e. about 5\% of the country surface, also provoking 112 fatalities.

In Figure 1 the location of the case study of Pedrógão Grande wildfire is presented. This event is one of the most disastrous fires ever occurred worldwide, with the highest number of fatalities (66) in a single event. Pedrógão Grande fire spread between $17^{\text {th }}$ and $20^{\text {th }}$ of June, i.e. out the usual fire season, and burned 28,624.7 ha. This wildfire reached intensities of $60,000 \mathrm{kWm}^{1}$ and during 10 minutes of its critical phase assumed a rate of spread (ROS) of $15 \mathrm{~km} / \mathrm{h}$, provoking most of the fatalities; it exhibited extreme phenomena of vorticity and of short and long-distance spotting activity (ADAI/LAETA 2017; CTI 2017). Its estimated magnitude was $568 \mathrm{GW}$, a very high value for Portugal, although it represented just one third of the potential magnitude in wildfires with higher intensity and ROS that already occurred in eucalyptus forests in Australia (CTI 2017). About 63\% of the fire perimeter burned in the first 24 hours, and 4,459 ha burned in a single hour.

In the area affected by the Pedrógão Grande fire, forests of Eucalyptus and Pinus pinaster dominate, with a high spatial continuity; the agricultural areas are small and located around the villages; grazing activity is low (1-3 livestock units per ha) (CTI 2017).
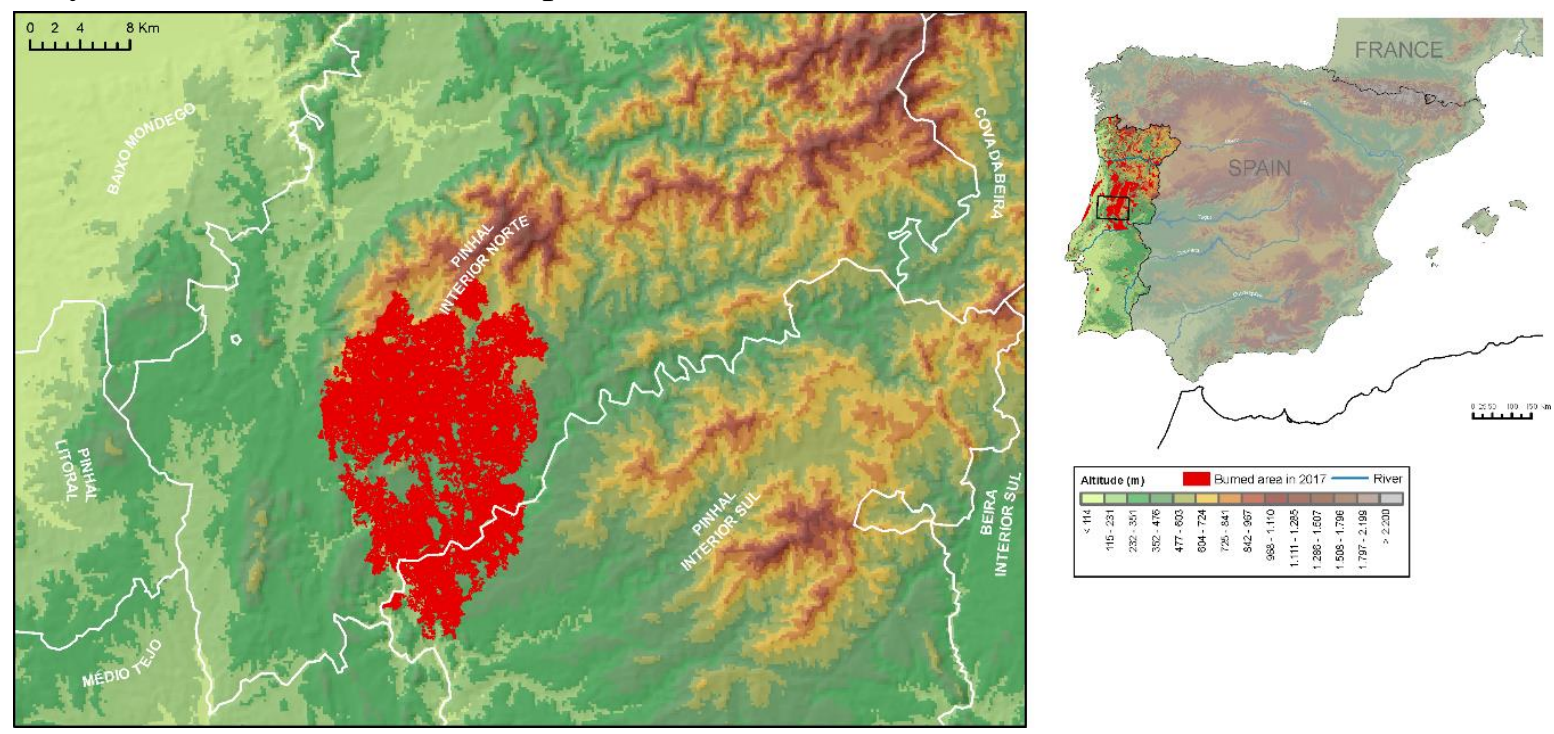

Figure 1 - Location of Portugal and the study area of Pedrógão Grande

\subsection{Data sources and processing}

\subsubsection{Wildfire dataset}

For the period 1975 to 2017, we used a dataset of wildfire perimeters polygons. To allow the comparability of our research with the findings of other studies about unburned areas (e.g., Meddens et al. 2018) we considered only the perimeters $\geq 405$ ha.

The data of burned area polygons for the period 1975-1989 were produced by the School of Agriculture (ISA - Instituto Superior de Agronomia). For the following years until 2017, we used the cartographic data available in the website of the Institute of Nature Conservation and Forests (ICNFInstituto de Conservação da Natureza e das Florestas). Furthermore, for the year 2017, we used also the dataset produced by ISA and provided by the Independent Technical Commission (CTI- Comissão Técnica Independente - created by the Portuguese Parliament to analyze the wildfire events occurred in 2017). Fire perimeters polygons considered in these datasets do not necessarily correspond to single 
wildfires, since a fire perimeter can be constituted by the coalescence of more than one fire or be a result of a single wildfire.

The two mentioned datasets used different procedures for the burned area detection and reveal different number of UPs, which shows that the mapping of fire perimeter can produce different numbers of UPs for the same event and, consequently, influences the consistency of the results. For instance, in the dataset provided by ICNF (accessed on April $3^{\text {rd }}$, 2018) 4,793 UPs were listed, of which 876 have an area $\geq 1$ ha (18.3\%). The dataset provided by the ISA, allowed the identification of 31,470 UPs, of which $8,172(25.9 \%)$ are $\geq 1$ ha. The same differences were obtained for the Pedrógão Grande wildfire (Fig. 2). While one of the datasets identifies just 45 UPs $\geq 1$ ha, from the other we obtained 522 UPs $\geq 1$ ha out of 2,039 UPs.

\subsubsection{Unburned areas database}

Unlike Meddens et al. (2016), who used random Forest and classification trees in order to separate burned from unburned locations, we estimated the unburned area by the application of geometrical operations. It means the difference between a rectangular polygon of the dimensions of each fire perimeter and the polygon of burned area, returning a new geometry only with the unburned area, excluding polygon rests which were outside the fire boundary.

a)

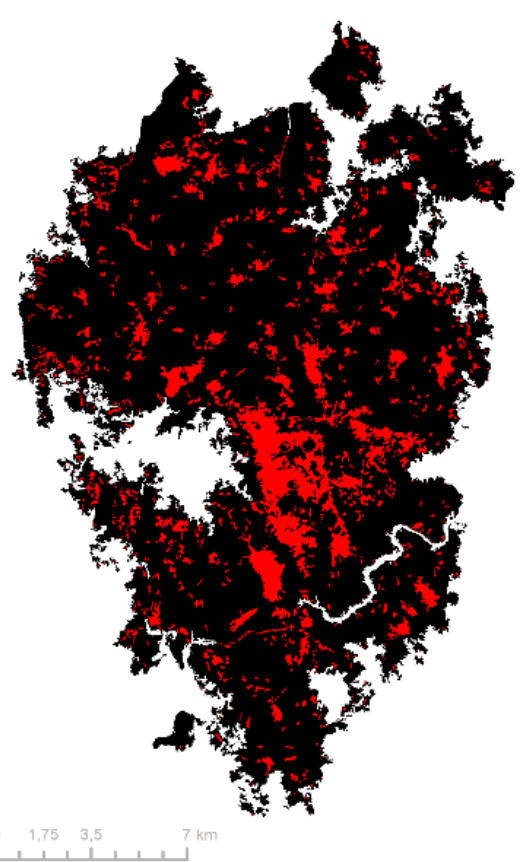

b)

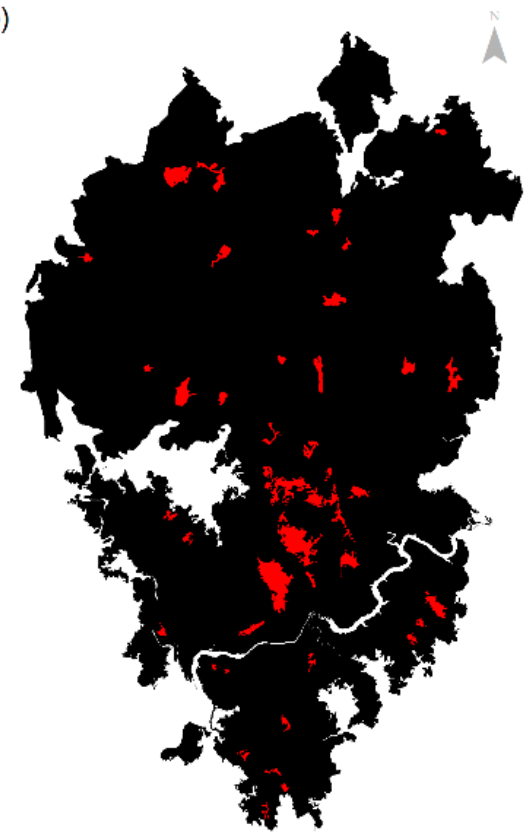

Figure 2 - The UPs in Pedrógão Grande wildfire using two different sources: a) ISA; b) ICNF

For Pedrógão Grande fire we also used the shape file of the isochrons of fire spread provided by CTI.

\subsubsection{WUI delimitation at national and local scale}

The mapping of WUI was carried out by the methods developed by the Institut National de Recherche en Sciences et Technologies pour l'Environnement et l'Agriculture (IRSTEA) and available in the Ruimap software (Sirca et al. 2017). The aim is to locate the different WUI types throughout the country in order to have an idea of WUI spatial patterns.

On the global scale, the WUI is defined by a radius of $400 \mathrm{~m}$ around houses located at less than 200 $\mathrm{m}$ from forests or shrubland. The mapping of the WUI for all Portugal using the global scale method was made on the Corine Land Cover for the year 2006, as more recent data on land use were not available. The pixel resolution is $100 \mathrm{~m}$. The WUI for the area affected by the Pedrógão Grande fire 
was also mapped using the local scale method developed in a French context by IRSTEA. In this case the WUI is defined by a radius of $100 \mathrm{~m}$ around each building located at a distance of less than $200 \mathrm{~m}$ from forests or shrublands.

Four housing configuration classes were created: isolated, scattered, dense clustered and very dense clustered housing. The WUI map was created by a combination of housing configuration and vegetation characterization or land use map; the result is a map of twelve WUI classes. For the local scale WUI mapping method applied to Pedrógão Grande fire, the input data for the buildings are from Copernicus Emergency Management Service, and the level 5 land use map of Portugal from DireçãoGeral do Território (DGT). The pixel resolution is $2.5 \mathrm{~m}$.

\subsection{UPs data analysis}

\subsubsection{National trends and spatial pattern}

The statistical analyses and illustration of the results were carried out in the $\mathrm{R}$ (3.5.) statistical environment (Team 2018), including the packages \{ggplot 2$\}$ for the graphics, the $\{s f\}$ for geometrical operations and the \{trend\} package for the Man-Kendall statistics. The linear trends in this study were estimated using the Mann-Kendall's tau test at the 95\% significance level (Libiseller and Grimvall 2002). The Man-Kendall statistic test is a rank-based nonparametric test, which has the advantage to be robust to outliers and does not assume an underlying probability distribution. For testing the correlation between different variables, the nonparametric Spearman's rank correlation coefficient was used at a 95\% significance level (Best and Roberts 1975). For the national scale, we combined the Portugal WUI with the UPs of the year 2017. The same procedure was used for Pedrógão Grande fire.

\subsubsection{UPs analysis in Pedrógão Grande fire study case}

As UPs are spatial entities, we used a pixel-based approach to investigate the factors contributing to UPs. The characterization of UPs was based on their number, size, and proportion within fire perimeter, density, and Euclidian distance using the method of nearest neighbor. Hence, we used a Digital Elevation Model (DEM) with a resolution of $25 \mathrm{~m}$, which enables us to estimate several terrain metrics: aspect, slope, elevation, Topographic Position Index (TPI) (Guisan et al. 1999) and the Terrain Ruggedness Index (Riley 1999). For the last two indices, a search radius of $1000 \mathrm{~m}$ and no distance weighting were considered. All the metric calculations were conducted in the SAGA-GIS software (version 6.3.0) by using the $\mathrm{R}$ package $\{R S A G A\}$. The morphometric indices describe different aspects of the terrain, which may play an important role in the explanation of the formation of UPs. In detail, TPI compares the elevation of each cell to the mean elevation of a specified neighborhood (identification of ridges and valleys); and TRI is the difference of elevation between a cell and the mean of an 8-cell neighborhood of surrounding cells.

The created UPs database includes several variables including the classification of UPs by their composition: Vegetation UPS constituted only by vegetation or land without any buildings; WUI UPs constituted only by WUI; and Mix UPs where WUI and vegetation areas coexist. Base map and Google Earth, both images from 2016, were used to verify the land use of each UPs, integrated by fieldwork.

\section{Results}

\subsection{National trends}

From 1975 to 2017 ; 894 fire perimeters $\geq 405$ ha were found. There is a high interannual variability in the number, with maximum values recorded in 2005 (143 perimeters), 1998 (116), 2003 (90), and 2017 (89) (Fig. 3a). The lowest number of fire perimeters with the mentioned size occurred in 1988 and 1997. Out of the observed 894 fire perimeters, just 305 (34.1\%) contained UPs in number of 6,413, with a high interannual variability (Fig. 3b). The years with the highest number of UPs are 2017, 2013, and 2003 (Fig. 4). Since 2000, fire perimeters $\geq 405$ ha with UPs can be found every year. 
a)

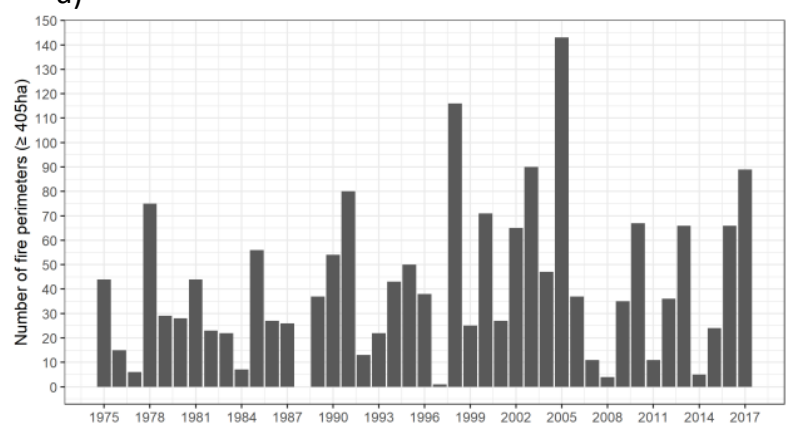

b)

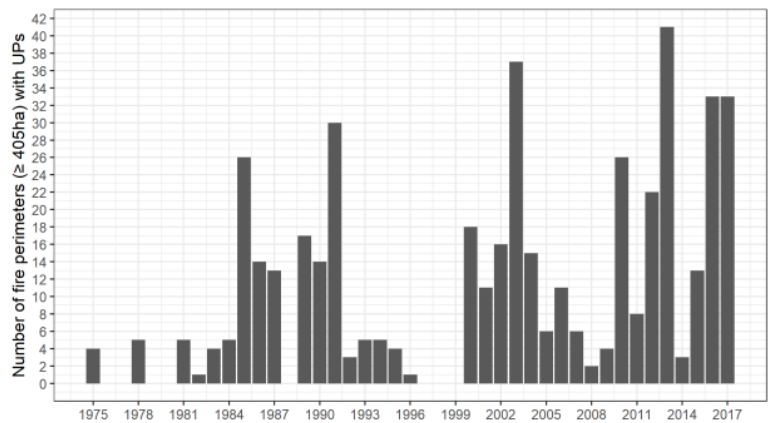

Figure 3 - a) Number of fire perimeters $\geq 405$ ha, from 1975 to 2017 , b) Number of fire perimeters $\geq 405$ ha with UPs, from 1975 to 2017 (Source: Data from ISA, ICNF)

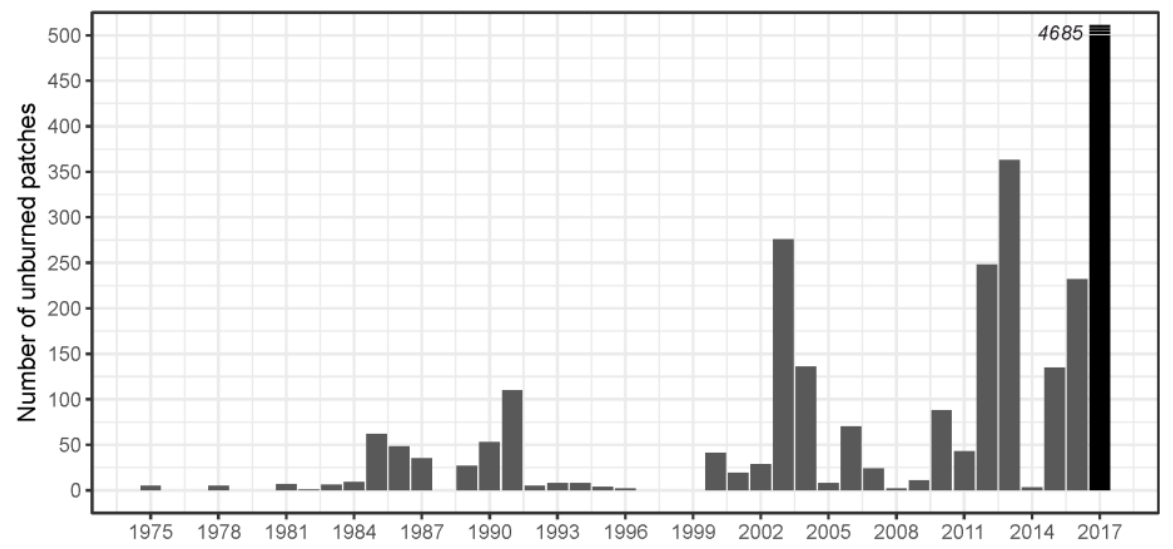

Figure 4 - Number of UPs in fire perimeters $\geq 405$ ha (Source: Data from ISA, ICNF).

For the whole period, 1975 to 2017, the area of UPs represented a proportion of 4,2\% within fire perimeters, with a range between $0.005 \%$ (for 2005) and $8.0 \%$ (for 1984, a year with very low BA in fires perimeters $\geq 405$ ha). Mann-Kendall trend test reveals positive trends for all the variables considered in the analysis: BA (tau $=0.2981 ; p$-value $=0.0056)$; UPs area (tau $=0.1901 ; p$ value $=0.0777)$; number of UPs ( $\operatorname{tau}=0.4021 ; p$-value $=0.0002)$; UPs density per 100 ha (tau=0.4354; $p$-value $\left.=5.031 \mathrm{e}^{-05}\right)$, and mean distance between UPs ( $\operatorname{tau}=0.3140 ; p$-value $\left.=0.0041\right)$. Spearman's rank correlation reveals a strong and statistically significant positive correlation between BA $\geq 405$ ha and UPs area inside those perimeters ( $r h o=0.8087 ; p$-value $=2.648 \mathrm{e}^{-07}$ ) (Fig. 5a). However, 2003, 2017 and 2005 are clearly highlighted as outliers: the first two exhibit a high number of BA and UPs area, whereas 2005 exhibits the third largest BA in the period, but a very low UPs area inside the perimeters $\geq 405$ ha. A strong positive and statistically significant correlation is observed between BA and the number of UPs $\left(r h o=0.8582 ; p\right.$-value $\left.=4.386 \mathrm{e}^{-11}\right)$ (Fig. $\left.5 \mathrm{~b}\right)$. The mean size of UPs ranges between 147.80 ha (1982) and 0.24 ha (2005). 
a)

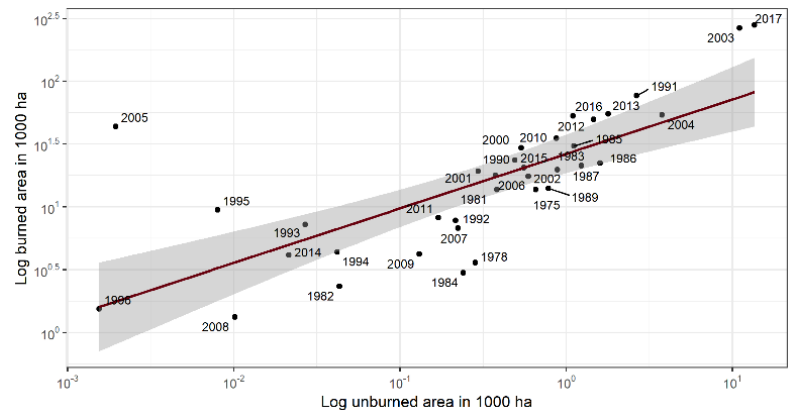

b)

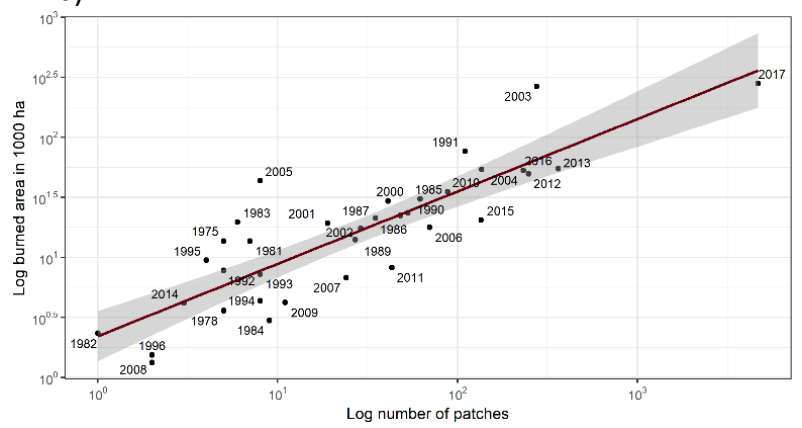

Figure 5 - Relationship between (a) BA and UPs area and (b) between BA and the number of UPs for fire perimeters $\geq 405$ ha

\subsection{The 2017 wildfire season in Portugal}

In the 2017 wildfires season in Portugal we identified 31,470 UPs occupying 55,591.4 ha within the BA. Most of the UPs had a very small size, and only 8,172 of them had a size $\geq 1$ ha. The mean size of the UPs is 1.8 ha (Q75\%: 1.0 ha; Q95\%: 4.8 ha; Q99\%: 23.7 ha), but within fire perimeters there are UPs larger than 100 ha, that is the threshold of large fires in Portugal. In fact, 63 UPs with $>100$ ha were found; the largest one reached 2,134.6 ha. The UPs density per 100 ha for all the fires considered in 2017 is 6.8. Wildfires did not only affect forest, shrubs and agricultural areas, but also $28.2 \%$ of the WUI of Portugal. Only 5.3\% of WUI inside the 2017 fire perimeters was not affected by fires and constitutes UPs. About 44.1\% (24,5 ha) of the area of UPs falls in WUI; $40.2 \%$ of it is characterized as isolated housing surrounded by forested area, followed by isolated housing surrounded by agricultural or sparse vegetation (34.2\%), and scattered housing surrounded by forested area (10.9\%) (Table A1, in Annex). UPs occurring in areas characterized as dense clustered housing, represented only 445 ha (1.8\% of UPs area within fire perimeters), a very low value, when compared with the other types of WUI.

\subsection{Pedrógão Grande wildfire}

Within Pedrógão Grande fire perimeter, there are 3,833.0 ha of WUI (Fig. 6) but just 1,705.9 ha did not burn, i.e. the $44.5 \%$ of the total affected area and about $13.5 \%$ (3,850.5 ha) of the total area within fire perimeter is constituted by 2,039 UPs. The density of UPs per 100 ha in Pedrógão Grande fire is 0.4. Since 1,517 UPs (representing $74 \%$ of the number and with a surface of 231.6 ha) have $<1$ ha, we found 522 UPs $\geq 1$ ha representing an area of 3,618.9 ha. The largest UP has 751.4 ha. The mean size of the UPs is 1.9 ha, but if we consider only the UPs $\geq 1$ ha, the value increases to 6.9 ha. Using the nearest neighbor method, the mean distance between UPs is $197.77 \mathrm{~m}(\mathrm{SD}= \pm 1,459.7 \mathrm{~m}$; maximum distance $=18.3 \mathrm{~m}$; minimum distance $=15.4 \mathrm{~m}$ ).

\subsubsection{The UPs composition}

Most of the UPs (No. $=1610)$ are vegetation UPs, but they only represent $29.1 \%$ of the unburned area. Most of area of the UPs $(2,632.8$ ha) belong to Mix UPs (No. $=267)$ and 164 UPs (Area $=2.6 \%$ ) are WUI UPs. The vegetation UPs mainly have a size $>1$ ha. Only 5 of them have more than 10 ha. The largest UPs (>50 ha), with the exception of one with 61.7 ha that is a vegetation UPs, are Mix UPS. 


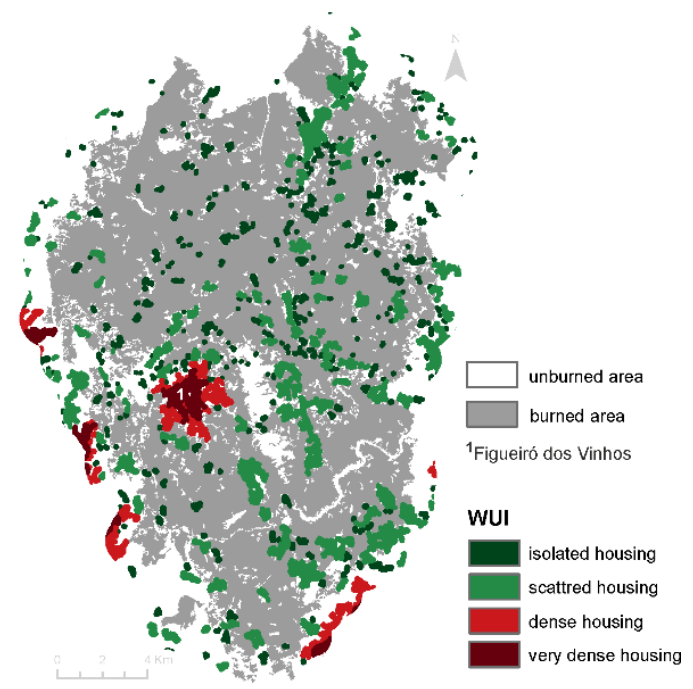

Figure 6 - The WUI within the Pedrogão Grande wildfire perimeter

\subsubsection{Terrain variables}

The terrain metrics used to explain the formation of UPs, reveal some differences between BA and UPs for all the descriptors (Table A2, in annex). Regarding the aspect, the distribution of BA and UPs seems typically bimodal, with the peaks for UPs at W and E (Fig. 7). The UPs distribution is more concentrated in some values of aspect than the one of BA. Making the analysis by the type and the size of UPs we can find that in all the situations most of the UPs are orientated to S and W (Table A3, in annex). In terms of elevation the two curves (Fig. 7) exhibit a similar mono-modal profile. The distribution of UPs seems more concentrated at lower elevation values with a lower SD $( \pm 113.20)$ than the BA. There are no significant differences in terms of size and type of UP. Regarding TRI, the BA curve presents a bimodal distribution with the two peaks with similar density but sharply right skewed. The curve of UPs is slightly different. The UPs are mostly located in lower level of TRI (level and nearly level). Although the TPI curves of BA and UPs seem almost overlapped, the latter exhibit more negative values which indicates the presence of valleys and gullies. In fact, most of the UPs $(1,038$ out of 2,039) are located in valleys. These results are corroborated by slope. It is evident that the distribution of UPs is more related with low values of slope. BA, on the contrary, are more associated with higher values of slopes and the curve exhibits some right skewness.

\subsubsection{UPs and wildfire intensity}

For the comparative analysis of the fire spread by time and the UPs location, we considered the time fire first arrived to the border of UPs. In many of the UPs fire spread around for less than 1 hour. In opposition, others faced the fire for many hours or saw it returning from another direction some hours after the first contact. The Pedrógão Grande fire burned with different intensities and ROS but since the first half an hour after the ignition, the fire burned above the extinction capacity (CTI 2017). In this EWE unburned area within fire boundary exists irrespective of fire intensity values. In the periods of higher intensity, it is possible to find a high number of UPs per hour (Fig. 8). On the $17^{\text {th }}$ of June between 19- 


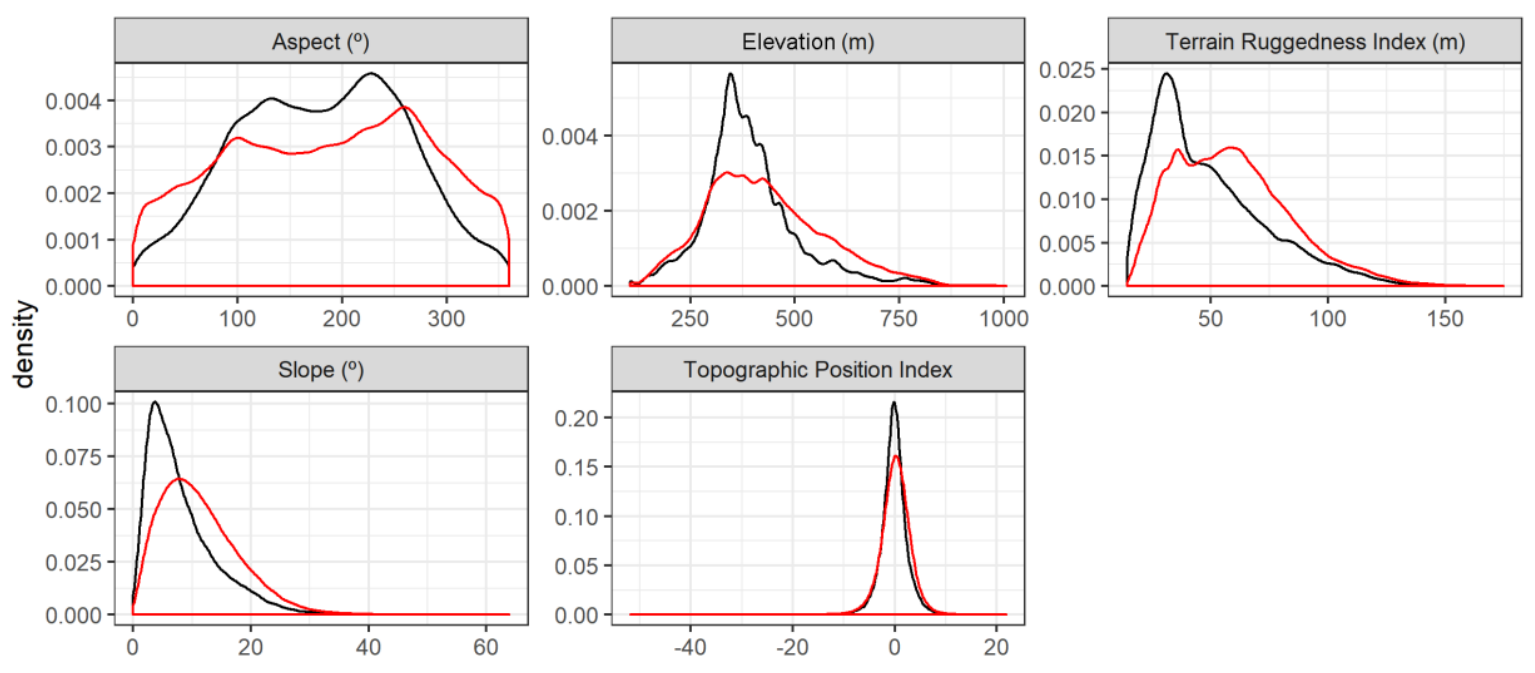

Figure 7- Probability density function of terrain metrics for BA and UPS (red line: BA; black line: UPs).

$20 \mathrm{~h}$, when fire burned with intensity up to $60,000 \mathrm{kWm}^{-1}$, we identified 82 UPs with a mean size of 6.0 ha. In the following hour, when the downburst occurred, the number of UPs reached 162. However, in the latter period the extent of the BA was higher than in the former $(4,458.6$ ha of BA between 20 $21 \mathrm{~h}$, vs. 2,588.7 ha between 19-20 h). The density of UPs in the two mentioned intervals was respectively 31.6 and $27.5 \mathrm{UPs} / 100 \mathrm{ha}$. In the following day between 15 and $17 \mathrm{~h}$, when the fire intensity approached again to $40,000 \mathrm{kWm}^{-1}$, the number of UPs arrived to 255 (i.e. a mean of 127.5 per hour) and the UPs density assumed a value of 13.2 UPs/100 ha.

On the first day of the wildfire, in the interval between 19 and $21 \mathrm{~h}$, UPs with different sizes and characteristics occurred. The less representative was the WUI UPS (29.0 ha; mean size of the patches 0.97 ha) most of them with less than 1 ha. The maximum size was 6.7 ha. The Vegetation UPs were more numerous (137) most of them with $<1$ ha (83) and represented 117 ha (mean size of the patches 0.9 ha). The Mix UPs occupied 1,632.3 ha. They reached a larger size (mean size is 21.2 ha; maximum size 751.9 ha), as only 16 out of 77 have <1 ha; three of them have more than 100 ha. While in Vegetation and WUI UPs we could not find patches with more than 10 ha, in Mix UPs we found 21 with such size out of the 244 UPs defined for the interval between 19-21 h. Most of these UPs consist of settlements surrounded by agricultural lands, sometimes associated with small pockets of caducifolious forests, small patches of very young Eucalyptus plantations, and patches of caducifolious species close to rivers. Less frequent was to find UPs with adult Eucalyptus plantations.

\section{Discussion}

\subsection{National trends}

In Portugal the maximum size of wildfires is increasing and the overall BA reached in 2017 values higher than the previous years. WUI area represents $26,4 \%$ of the country total surface, which is a high value comparatively with other countries. For instance, South of France has only $11 \%$ of WUI (LongFournel, 2013). 


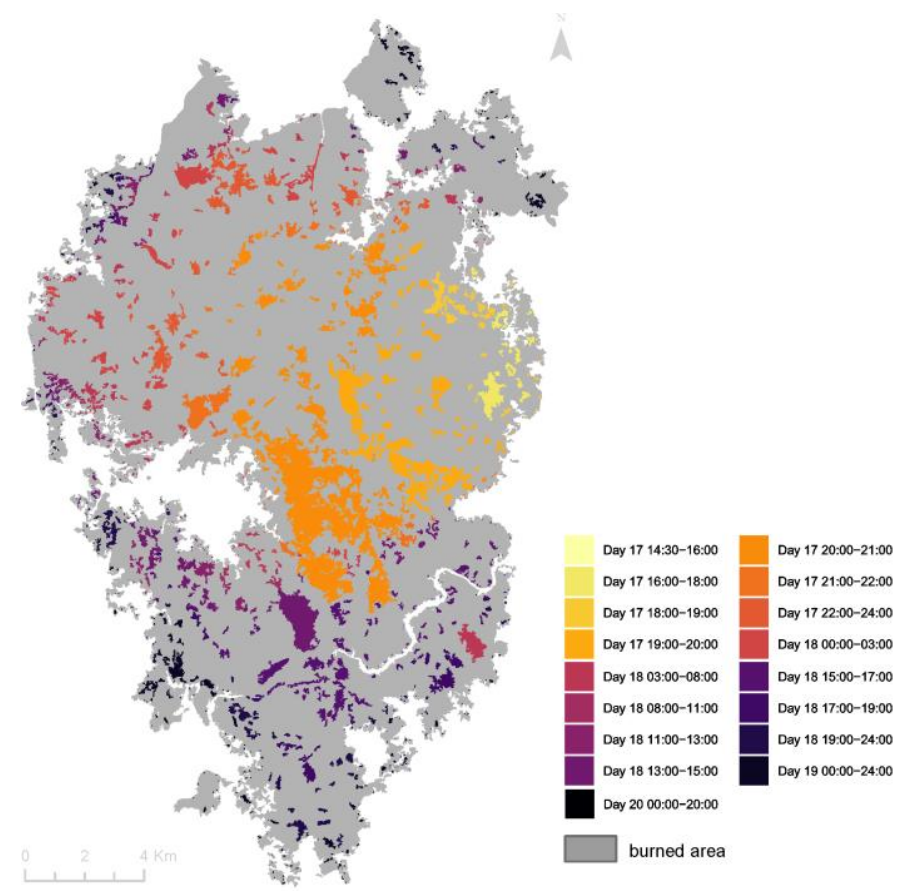

Figure 8 - Pedrógão Grande fire: Chronology of UPs appearance. The highest values of fire intensity were registered between 19 and 21 h of June $17^{\text {th }}$.

Portugal presents a high interannual variability in terms of unburned area within fire perimeters. The BA, UPs area, number of UPs are increasing in fire perimeters $\geq 405$ ha. We found a strong and positive correlation between BA and the number of Ups, as well as with the UPs area. However, we are only dealing with large fire perimeter. Nevertheless, some years presented a different behavior. For instance, 2005 is the third year with more BA but has very few UPs in fire perimeters $\geq 405$ ha. This situation deserves a deep research. In the general case of Portugal, positive trends with statistical significance were found for UPs area, number of patches, UPs density, and mean distance between patches. Our findings are in contrast with previous studies in other parts of the world where no trend was found (Meddens et al., 2018; Kolden et al. 2012, 2015).

In Portugal, the WUIs are mainly concerned by a higher fire ignition density than other areas (Bouillon et al., 2013). Isolated WUI is the most representative class, and dwellings located in the forest increase the risk for people and assets. In general, the presence of forest surrounding any type of settlement, including isolated housing, is accompanied by the increased likelihood of being affected by wildfires and suffer damage, even though the highest danger is for isolated housing. In term of proneness to be affected by wildfires, isolated housing represents the most critical situation followed by scattered housing. Dense settlements, on the contrary, seem to represent the less critical condition. But when we look at the characteristics of WUI areas that burned and the WUI UPs we found that most of the WUI UPs that did not burn were also isolated housing surrounded by forest, followed by isolated housing surrounded by agricultural lands. Of course, the presence of forest is a variable issue, as it depends on the type of forest and its condition of management, and secondarily on the distance between the edge of the forest and the buildings, as well as on fire intensity and spotting characteristics. The presence of agricultural land around the settlements does not guarantee assets protection and safety. Its efficaciousness in protecting assets mostly depends on conditions of combustibility and flammability of vegetation on the fields, in turn depending on its moisture content, its vegetative stage, and soil moisture content.

In this research we used fire perimeters produced by official organizations. We cannot guarantee that for the period of 1975 to 2017 the methodology used to map the fire perimeters has been uniform; the interpretation of satellite-derived severity can be distinctive and we are not aware if the data were 
calibrated with ground data. At the same time satellite imagery has developed a lot in that period as well as the methodologies of interpretation. If the existence of long dataset could be required to produce a better understanding of the dynamic of UPs formation and characteristics, some problems of data comparability can exist. Hence, we do not excessively valorize the results obtained for the UPs trends. The evaluation of WUI characteristic should be done with more recent land cover and land use data to validate our findings. Thus, we prefer to focalize on the findings from the case-study of Pedrógão Grande, where the mentioned potential weaknesses are not present.

\subsection{Pedrógão Grande wildfire}

Previous studies showed that in all types of wildfires (ranging from crown-fires to surface fires in grassland) it is possible to find heterogeneous patterns of fire severity including UPs (Bradstock 2008; Kolden et al. 2012). Some of UPs studies investigated the influence of fire severity in the appearance of unburned areas (Kolden et al. 2012). Our research is based on the influence of fire intensity on the UPs formation and confirms that it is possible to find UPs in case of EWEs.

In the large and high intensity Pedrógão Grande fire, UPs represented a significant percentage $(11.9 \%)$ of the area affected by the wildfire. This result is particularly interesting because Leonard et al. (2014) in the Kilmore East-Murrindindi fire complex found that UPs comprised less than one percent of the total fire area; both fires were EWEs although with different values of intensity (maximum intensity in Pedrógão Grande was $60,000 \mathrm{kWm}^{-1}$ (CTI 2017), whereas in the Australian case-study it reached up to $90,000 \mathrm{kWm}^{-1}$ (Cruz et al. 2012). The magnitude for Pedrógão Grande (568 $\mathrm{GW}$ ) was almost three times lower than the ones for the mentioned Australian fires (respectively, Kilmore East 1537 GW and Murrindindi 1642 GW; Harris et al. 2011; CTI 2017).

In the case of Pedrógão Grande, in the period of highest intensity, we found the highest number of UPs per hour and also the patches with larger size. Our study does not confirm that an increase in fire intensity produces smaller unburned areas (Kolden et al. 2012; Kolden et al. 2015; Meddens et al. 2018).

Concerning the terrain metrics influencing UPs, in our study case TPI is the one that more strongly influences their occurrence. Our results are aligned with previous studies (e.g., Leonard et al. 2014; Krawchuk et al. 2016). Slope findings corroborate previous studies (e.g., Ramon-Cuesta et al., 2009); we found UPs in very different slope conditions, including values $>50^{\circ}$, although most of them appear on slopes with very low values. On the contrary, our results contradict the recurrent opinion that unburned areas occur more frequently under the influence of $\mathrm{N}$ aspect (e.g. Ramon-Cuesta et al., 2009). In our case the most favorable aspects resulted $\mathrm{S}$ and $\mathrm{W}$.

We found UPs with very different size and characteristics. If in the smaller UPs we can identify a particular type of land use (e.g., a very young plantation of eucalyptus, a small area of caducifolious forest, a small settlement) that distinguish the unburned area from the surrounding, in the larger UPs we found heterogeneity of uses. The larger UPs found in Pedrógão Grande fire that we labelled as Mix UPs comprise different land uses.

Although the presence of forest around the settlements and mainly around isolated housing marks the riskiest condition, the relation is not so linear as we found many UPs constituted by isolated housing surrounded by forest. In parallel, the existence of an agricultural area surrounding the settlements is not a guarantee of protection. It depends on the extension, the composition, and the management of the vegetation.

The characteristics of UPs show that the big and very costly creation by the Portuguese Government of a primary network of fuel management is not necessarily the most effective in abating fire intensity. For normal fires (Tedim et al. 2018) this could have some efficacy, but in case of EWEs this kind of fuel management results absolutely useless because of the intensity and spotting activity, that can spread fire at distances of several $\mathrm{km}$ from the front of the fire. 


\section{Conclusion}

Unburned areas have been mostly analyzed using an ecological approach, but there are no studies, on our knowledge, concerning the contribution of WUI characteristics in the UPs formation. Our results must be considered absolutely innovative regarding this point, because they are quantitatively referred to categories of WUI.

The understanding of the trends and spatial patterns of UPs, mainly in the case of EWEs, is crucial to inform wildfire and land management as well as spatial planning. UPs exert important ecological benefits and influence ecosystem and communities' resilience, but they also allow to understand how to increase the efficacy of prevention and mitigation activities (e.g., to planning safer settlements location and WUI expansion).

Most of the studies relate unburned areas with severity, that is a local response of the landscape to physical characteristics of the fire; thus, we preferred to focus on the fire behavior to understand how it can affect the formation of UPs. Pedrógão Grande wildfire shows that also an EWE is able to create UPs under the complex interaction of fire behavior with fire environment, topography, vegetation, landscape characteristics, namely the WUI characteristics. The diversity of characteristics exhibited by the UPs shows that their formation is not tied to static landscape characteristics (e.g., slope, aspect, TPI) but they occur as a result of complex interactions of those factors with the dynamic factors of landscape, mainly local ones. A management goal should ensure enough landscape heterogeneity in order to maintain a consistent pattern of UPs, through the reduction of continuity of forest cover and the increase of mosaic patterns that help to provide a higher density of UPs and possibly an increase in their average size; the type and size of mosaic should be adapted to the fire regime of the different regions (e.g., low frequency, high intensity, large size; high).

Considering that fuel management is a very costly activity and exploiting the finding of our research that Mix UPS are larger than the ones with vegetation and WUI UPS, a gradual trend toward Mix UPs should be recommended as a basic model to orientate fuel management and spatial planning. This represents an advantage because inside these Mix UPs there are activities that manage the fuels, so ensuring relevant reduction of vulnerability and increase in the resilience of the territory which is one of the milestones of the new paradigm of "coexist with fire". In this direction the maintenance of productive activities (agriculture, grazing) that can break landscape continuity and connectivity can contribute to decrease vulnerability of local communities and, consequently, losses and damage. At the same time, while fuel reduction activities are very costly and difficult to implement in certain places because of the lack of work force, reducing the risk of wildfire by the introduction or maintenance of agriculture and grazing (mixing traditional with modern models of sustainable agriculture) with a high contribution to sustainable development, should be considered with priority within the measures of prevention against unwanted wildfires diffusion and spread. It is fundamental to be effective in the implementation of the United Nations Sustainable Development Goals.

\section{Acknowledgments}

This work was prepared in the frame of project FIREXTR- Prevent and prepare society for extreme fire events: the challenge of seeing the "forest" and not just the "trees" (FCT Ref: PTDC/ATPGEO/0462/2014), of which the first author is team leader, co-financed by the European Regional Development Fund (ERDF) through the COMPETE 2020 - Operational Program Competitiveness and Internationalization (POCI Ref: 16702) and national funds by FCT-Foundation for Science and Technology, Portugal. The authors would like to thank Comissão Técnica Independente for providing the shape files of Pedrógão Grande Fire perimeter and isochrons of the fire spread that were used in this study. 


\section{References}

ADAI/LAETA, 2017. O complexo de incêndios de Pedrógão grande e concelhos limítrofes, iniciado a 17 de junho de 2017. Faculdade de Ciências e Tecnologia Universidade de Coimbra.

Best, D, Roberts, D (1975) Algorithm AS 89: the upper tail probabilities of Spearman's rho. Journal of the Royal Statistical Society. Series C (Applied Statistics) 24, 377-379.

Birch, DS, Morgan, P, Kolden, CA, Hudak, AT, Smith, AM (2014) Is proportion burned severely related to daily area burned? Environmental Research Letters 9, 064011.

Bradstock, RA (2008) Effects of large fires on biodiversity in south-eastern Australia: disaster or template for diversity? International Journal of Wildland Fire 17, 809-822.

Corona, P, Ascoli, D, Barbati, A, Bovio, G, Colangelo, G, Elia, M, Garfi, V, Iovino, F, Lafortezza, R, Leone, V (2014) Integrated forest management to prevent wildfi res under mediterranean environments. Annals of Silvicultural Research 38, 24-45.

Cruz, M, Sullivan, A, Gould, J, Sims, N, Bannister, A, Hollis, J, Hurley, R (2012) Anatomy of a catastrophic wildfire: the Black Saturday Kilmore East fire in Victoria, Australia. Forest Ecology and Management 284, 269-285.

CTI, 2017. Análise e apuramento dos factos relativos aos incêndios que ocorreram em Pedrógão Grande, Castanheira de Pêra, Ansião, Alvaiázere, Figueiró dos Vinhos, Arganil, Góis, Penela, Pampilhosa da Serra, Oleiros e Sertã entre 17 e 24 de junho de 2017. Assembleia da República.

Eberhart, KE, Woodard, PM (1987) Distribution of residual vegetation associated with large fires in Alberta. Canadian Journal of Forest Research 17, 1207-1212.

Gill, AM, Moore, P (1998) Big versus small fires: the bushefires of greater Sidney, January 1994 In 'Large forest fires.' (Ed. JM Moreno.) (Backhuys Publishers).

Guisan, A, Weiss, SB, Weiss, AD (1999) GLM versus CCA spatial modeling of plant species distribution. Plant Ecology 143, 107-122.

Harris, S, Anderson, A, Kilinc, M, Fogarty, L (2011) 'Establishing a link between the power of fire and community loss: the first step towards developing a bushfire severity scale.' (Victorian Government Department of Sustainability and Environment).

Keane, RE, Agee, JK, Fulé, P, Keeley, JE, Key, C, Kitchen, SG, Miller, R, Schulte, LA (2009) Ecological effects of large fires on US landscapes: benefit or catastrophe? International Journal of Wildland Fire 17, 696-712.

Kolden, CA, Abatzoglou, JT, Lutz, JA, Cansler, CA, Kane, JT, Wagtendonk, JWV, Key, CH (2015) Climate contributors to forest mosaics: ecological persistence following wildfire. Northwest Science 89, 219-238.

Kolden, CA, Lutz, JA, Key, CH, Kane, JT, van Wagtendonk, JW (2012) Mapped versus actual burned area within wildfire perimeters: Characterizing the unburned. Forest Ecology and Management 286, 38-47.

Kolden, CA, Weisberg, PJ (2007) Assessing accuracy of manually-mapped wildfire perimeters in topographically dissected areas. Fire Ecology 3, 22-31.

Krawchuk, MA, Haire, SL, Coop, J, Parisien, MA, Whitman, E, Chong, G, Miller, C (2016) Topographic and fire weather controls of fire refugia in forested ecosystems of northwestern North America. Ecosphere 7.

Leonard, SWJ, Bennett, AF, Clarke, MF (2014) Determinants of the occurrence of unburnt forest patches: Potential biotic refuges within a large, intense wildfire in south-eastern Australia. Forest Ecology and Management 314, 85-93. 
Libiseller, C, Grimvall, A (2002) Performance of partial Mann-Kendall tests for trend detection in the presence of covariates. Environmetrics: The official journal of the International Environmetrics Society 13, 71-84.

Lutz, JA, Key, CH, Kolden, CA, Kane, JT, van Wagtendonk, JW (2011) Fire Frequency, Area Burned, and Severity: A Quantitative Approach to Defining a Normal Fire Year. Fire Ecology 7, 51-65.

Meddens, AJ, Kolden, CA, Lutz, JA, Abatzoglou, JT, Hudak, AT (2018) Spatiotemporal patterns of unburned areas within fire perimeters in the northwestern United States from 1984 to 2014. Ecosphere 9.

Riley, SJ (1999) Index that quantifies topographic heterogeneity. Intermountain Journal of sciences $\mathbf{5}$, 23-27.

Sirca, C, Casula, F, Bouillon, C, García, BF, Fernández Ramiro, MM, Molina, BV, Spano, D (2017) A wildfire risk oriented GIS tool for mapping Rural-Urban Interfaces. Environmental Modelling \& Software 94, 36-47.

Slik, JF, van Beek, M, Bernard, C, Bongers, F, Breman, FC, Cannon, CH, Sidiyasa, K (2011) Limited edge effects along a burned-unburned Bornean forest boundary seven years after disturbance. Biotropica 43, 288-298.

Team, RC, 2018. R: A Language and Environment for Statistical Computing, R Foundation for Statistical Computing, Austria, 2015. ISBN 3-900051-07-0: URL http://www. R-project. org.

Tedim, F, Leone, V, Amraoui, M, Bouillon, C, Coughlan, M, Delogu, G, Fernandes, P, Ferreira, C, McCaffrey, S, McGee, T, Parente, J, Paton, D, Pereira, M, Ribeiro, L, Viegas, D, Xanthopoulos, G (2018) Defining Extreme Wildfire Events: Difficulties, Challenges, and Impacts. Fire 1, 9.

Tedim, F, Remelgado, R, Carvalho, S, Martins, J (2015) The largest forest fires in Portugal: the constraints of burned area size on the comprehension of fire severity. Journal of Environmental Biology, 36(1):133-143.

Tedim, F, Remelgado, R, Martins, J, Carvalho, S (2013) Os grandes incêndios florestias em Portugal desafios para a gestão do risco In A. B. Gonçalves e A. Vieira (Eds.) Grandes incêndios florestais, erosão, degradação e medidas de recuperação dos solos, Guimarães, NIGP-Nucleo de Investigação em Geografia e Planeamento, Universidade do Minho 75-86.

Vaillant, NM, Kolden, CA, Smith, AM (2016) Assessing landscape vulnerability to wildfire in the USA. Current Forestry Reports 2, 201-213. 


\section{Annex}

Table A1: The WUI affected by fire in 2017, in Portugal

\begin{tabular}{|c|c|c|c|c|c|c|}
\hline \multirow{2}{*}{$\begin{array}{l}\text { Type of wildland- } \\
\text { urban interface }\end{array}$} & \multicolumn{2}{|c|}{ Burnt WUI in 2017 wildfires } & \multicolumn{2}{|c|}{$\begin{array}{c}\text { UPs in WUI in } 2017 \\
\text { wildfires }\end{array}$} & \multicolumn{2}{|c|}{ WUI Portugal } \\
\hline & $\mathrm{Ha}$ & $\%$ & Ha & $\%$ & Ha & $\%$ \\
\hline $\begin{array}{l}\text { Isolated housing - } \\
\text { mineral area }\end{array}$ & 747 & 0.6 & 223 & 0.9 & 3,450 & 0.1 \\
\hline $\begin{array}{l}\text { Isolated housing - } \\
\text { agricultural or sparse } \\
\text { vegetation }\end{array}$ & 18,869 & 14.4 & 8,384 & 34.2 & 691,831 & 28.4 \\
\hline $\begin{array}{l}\text { Isolated housing - } \\
\text { forested area }\end{array}$ & 82,653 & 63.0 & 9,867 & 40.2 & 906,432 & 37.8 \\
\hline $\begin{array}{l}\text { Scattered housing - } \\
\text { mineral area }\end{array}$ & 1,06 & 0.8 & 679 & 2.8 & 111,072 & 4.6 \\
\hline $\begin{array}{l}\text { Scattered housing - } \\
\text { agricultural or sparse } \\
\text { vegetation }\end{array}$ & 4,575 & 3.5 & 2,257 & 9.2 & 260,083 & 10.7 \\
\hline $\begin{array}{l}\text { Scattered housing - } \\
\text { forested area }\end{array}$ & 20,242 & 15.4 & 2,67 & 10.9 & 331,484 & 13.6 \\
\hline $\begin{array}{lr}\begin{array}{l}\text { Dense } \\
\text { housing }\end{array} & \text { clustered } \\
\text { area } & \text { mineral }\end{array}$ & 373 & 0.3 & 130 & 0.5 & 47,649 & 2.0 \\
\hline $\begin{array}{l}\text { Dense clustered } \\
\text { housing - agricultural } \\
\text { or sparse vegetation }\end{array}$ & 276 & 0.2 & 42 & 0.2 & 28,438 & 1.2 \\
\hline $\begin{array}{lr}\begin{array}{l}\text { Dense } \\
\text { housing }\end{array} \text { - } & \text { forested } \\
\text { area } & \end{array}$ & 2,424 & 1.9 & 273 & 1.1 & 57,587 & 2.4 \\
\hline Total & 131,219 & 100 & 24,525 & 100 & $2,438,026$ & 100 \\
\hline
\end{tabular}

Table A2: Summary of explanatory terrain metrics variables for UPs and BA in Pedrógão Grande wildfire

\begin{tabular}{|c|c|c|c|c|c|}
\hline Metrics & $\begin{array}{l}\text { Type of } \\
\text { area }\end{array}$ & Mean & $\pm \mathrm{SD}$ & Max & Min \\
\hline \multirow{2}{*}{ Aspect $\left({ }^{\circ}\right)$} & $\mathrm{BA}$ & 205.53 & \pm 2.05 & 360.00 & 0.00 \\
\hline & UPs & 182.95 & \pm 1.51 & 359.99 & 0.00 \\
\hline \multirow{2}{*}{ Elevation (m) } & $\mathrm{BA}$ & 426.98 & \pm 142.98 & 1006.34 & 105.36 \\
\hline & UPs & 391.77 & \pm 113.20 & 978.18 & 105.36 \\
\hline \multirow{2}{*}{ Slope $\left(^{\circ}\right)$} & $\mathrm{BA}$ & 11.28 & \pm 6.62 & 63.94 & 0.00 \\
\hline & UPs & 8.21 & \pm 0.11 & 61.29 & 0.00 \\
\hline Topographic & $\mathrm{BA}$ & 0.11 & \pm 3.00 & 21.84 & -51.90 \\
\hline Index & UPs & -0.23 & \pm 2.66 & 14.85 & -39.36 \\
\hline Ruggedness & $\mathrm{BA}$ & 11.27 & \pm 0.12 & 63.94 & 0.00 \\
\hline Index & UPs & 49.10 & \pm 24.63 & 172.60 & 14.15 \\
\hline
\end{tabular}


Table A3: Terrain metrics by UPS size and type of WUI in Pedrógão Grande wildfire

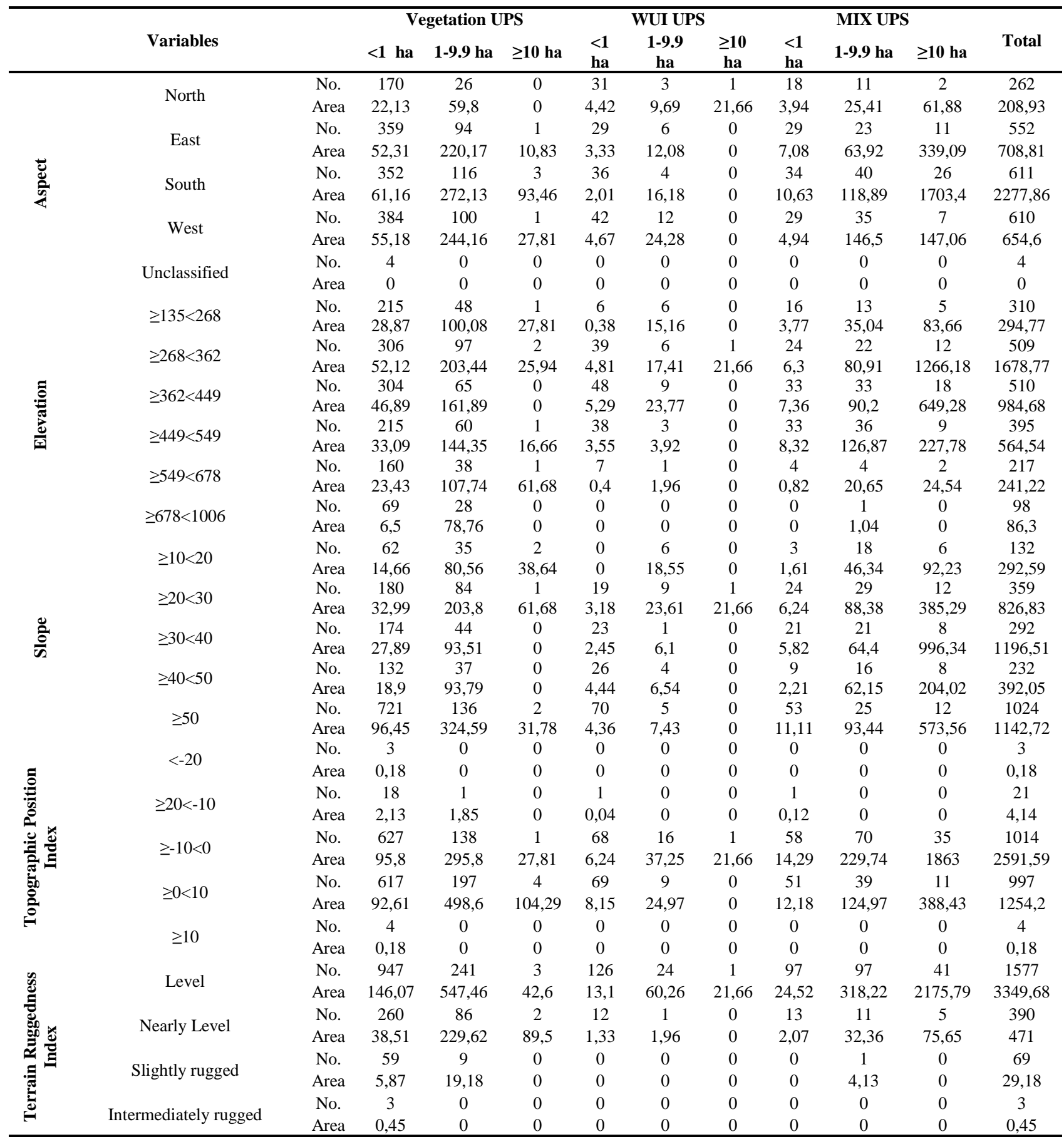

